\title{
An elusive new species of gymnophthalmid lizard (Cercosaurinae, Selvasaura) from the Andes of northern Peru
}

\author{
Lourdes Y. Echevarría ${ }^{1,2}$, Pablo J. Venegas ${ }^{2,3,4}$, Luis A. García-Ayachi' ${ }^{2,3}$, Pedro M. Sales Nunes ${ }^{5}$ \\ 1 Pontificia Universidade Católica do Rio Grande do Sul (PUCRS), Laboratório de Sistemática de Vertebrados. Av. Ipiranga 6681, Porto \\ Alegre, RS 90619-900, Brazil \\ 2 División de Herpetología, Centro de Ornitología y Biodiversidad (CORBIDI), Santa Rita No. 105 Of. 202, Urb. Huertos de San Antonio, \\ Surco, Lima, Peru \\ 3 Instituto Peruano de Herpetología (IPH), Augusto Salazar Bondy 136, Urb. Higuereta, Surco, Lima, Peru \\ 4 Rainforest Partnership, 4005 Guadalupe St., Austin, Texas 78751, USA \\ 5 Universidade Federal de Pernambuco, Departamento de Zoologia, Avenida Professor Moraes Rego, 1235, 50670-901, Recife, PE, Brazil \\ http://zoobank.org/B89E2829-6226-4A40-82E6-CDDDA6987C1C \\ Corresponding author: Lourdes Y. Echevarría (lourdese.20@gmail.com)
}

Academic editor: Alexander Haas • Received 11 May 2021 • Accepted 25 June 2021 • Published 27 July 2021

\begin{abstract}
We describe a new species of Selvasaura from the montane forests of the eastern slopes of the Andes in northern Peru, based on external and hemipenial morphological characters and previous phylogenetic analyses. The new species can be differentiated from the other two Selvasaura species in having keeled dorsal scales usually flanked by longitudinal striations, in adults and juveniles; adult males with a yellow vertebral stripe bordered by broad dark brown stripes on each side and a unilobed hemipenis surrounded by the branches of the sulcus spermaticus. The description of the new species contributes information about new states of diagnostic characters of Selvasaura and natural history.
\end{abstract}

\section{Key Words}

Arboreality, Bromeliad, Gymnophthalmidae, Hemipenial morphology, Peruvian Yungas ecoregion, Taxonomy

\section{Introduction}

The subfamily Cercosaurinae is the most diverse taxon of Gymnophthalmidae, currently containing 22 genera. In the last five years, several Cercosaurinae genera have been described or resurrected (e.g., Torres-Carvajal et al. 2016; Sánchez-Pacheco et al. 2018; Lehr et al. 2019, 2020; Vásquez-Restrepo et al. 2020; Rojas-Runjaic et al. 2021). The fast pace of generation of knowledge about the diversity of Cercosaurinae is, in part, due to the inclusion of samples from little-surveyed localities in recently published phylogenies (Goicoechea et al. 2013, 2016; Torres-Carvajal et al. 2016; Sánchez-Pacheco et al. 2017; Moravec et al. 2018; Fang et al. 2020; Mamani et al. 2020; Vásquez-Restrepo et al. 2020). These studies have revealed that the highly diverse montane forests of the eastern slopes of the Andes of Peru
(Young and León 2000) harbor new and endemic lineages of Cercosaurinae lizards (Goicoechea et al. 2013; Chávez and Catenazzi 2014; Echevarría et al. 2015; Mamani et al. 2015, 2020; Venegas et al. 2016; Chávez et al. 2017; Moravec et al. 2018; Lehr et al. 2019, 2020; Torres-Carvajal et al. 2020).

A clade of microteiid lizards, including samples from Ecuador and Peru, was identified as not nested in any recognized Cercosaurinae genus by Torres-Carvajal et al. (2016). Subsequently, Moravec et al. (2018) described this clade as the genus Selvasaura, including a single species, S. brava Moravec, Šmid, Štundl \& Lehr, 2018, an arboreal lizard from the eastern montane forests of the Andes of central Peru. Another species of Selvasaura was described from the Amazonian slopes of the Andes of Ecuador based on morphological and molecular data (Torres-Carvajal et al. in press). In their phylogenetic tree, 
Torres-Carvajal et al. (in press) recovered an unnamed clade of Selvasaura from northern Peru sister to S. brava in agreement with previous studies (Torres-Carvajal et al. 2016; Moravec et al. 2018; Fang et al. 2020). Based on external and hemipenial morphological characters here we describe this clade as a new species of Selvasaura from the montane forests of northern Peru.

\section{Materials and methods}

\section{Field surveys}

Specimens were collected during four field surveys conducted between 2014 and 2020. Field surveys to Laurel and Fundo Alto Nieva, in San Martín department, were conducted during the wet season in November 2014 and January 2020, respectively. Surveys in Amazonas department, at Copal and Quebrada Gajmal, were conducted in June 2017 and October 2018 during the dry season and transition from dry to wet season, respectively. Anurans and reptiles were actively searched using the visual encounters (VES) method (Crump and Scott 1994) and collected by hand. All collected specimens were preserved in 10\% formalin and stored in 70\% ethanol (Barry 2012). Tissue samples were taken from the liver, tail or tongue and stored in 96\% ethanol. Type specimens were deposited in the herpetological collection at Centro de Ornitología y Biodiversidad (CORBIDI) in Lima, Peru.

\section{Morphology}

The following measurements were taken, to the nearest $0.1 \mathrm{~mm}$, with a digital caliper: head length (HL), head width (HW), shank length (ShL), axilla-groin distance (AGD), and snout-vent length (SVL). Tail length (TL) was measured with a ruler and recorded to the nearest millimeter. Except for males with everted hemipenes, a short incision in the base of the tail was made to check for the presence of hemipenes. The volume of oviductal eggs was calculated in two gravid females (CORBIDI 15118 and 15120) with the formula for a prolate spheroid $\mathrm{V}=4 / 3 \pi$.(length/2).(width/2) ${ }^{2}$. We described the coloration in life from photographs.

Definitions of morphological characters follow $\mathrm{Ki}$ zirian (1996). The format of the description follows Moravec et al. (2018) and Torres-Carvajal et al. (2014). For comparisons, morphological information was taken from Moravec et al. (2018), Torres-Carvajal et al. (in press) and examination of type specimens (Appendix 1). The Selvasaura species described by Torres-Carvajal et al. (in press) will be referred to as Selvasaura sp. Ecuador.

\section{Hemipenial morphology}

The left hemipenis of the holotype CORBIDI 15119 was prepared following the procedures described by Manzani and Abe (1988), modified by Pesantes (1994) and Zaher
(1999). The organ was everted after immersion in potassium hydroxide solution for approximately 15 minutes. The retractor muscle was manually separated, and the everted organ filled with stained petroleum jelly. The organ was then immersed in alcoholic solution of Alizarin Red for 24 hours in order to stain calcified structures (e.g., spines or spicules), in an adaptation proposed by Nunes et al. (2012) of the procedures described by Uzzell (1973) and Harvey and Embert (2008). The terminology of hemipenial structures follows previous literature (Nunes et al. 2012).

\section{Genetic distances}

We used MEGA (Kumar et al. 2016) to calculate uncorrected genetic distances for $12 \mathrm{~S}$ (337 pb fragment), 16S (452 pb fragment), c-mos (381 pb fragment), and ND4 (621 pb fragment). Uncorrected genetic distances were calculated between $S$. brava, $S$. sp. Ecuador, the new species, and $S$. sp. QCAZ 12891 (an undescribed species from Ecuador). For ND4 uncorrected genetic distances did not include Selvasaura brava, once there is no available data for ND4 from this species.

\section{Species concept}

We followed the evolutionary species concept (Simpson 1951; Wiley 1978; de Queiroz 1998, 2007). We used morphological features to diagnose as a species a monophyletic group previously inferred through phylogenetic analysis of DNA sequences.

\section{Results}

The allocation of the new species in the genus Selvasau$\mathrm{ra}$ is based on previously published phylogenetic evidence (Torres-Carvajal et al. 2016, in press; Moravec et al. 2018). Phylogenetic divergences presented in earlier studies (Torres-Carvajal et al. 2016, in press; Moravec et al. 2018) and the combination of diagnostic morphological characters (external and hemipenial) allowed the identification of the specimens in our hands as an unnamed Selvasaura species, described below.

Uncorrected genetic distances among Selvasaura were $4.8-6.3 \%$ for $12 \mathrm{~S} ; 4.7-5.2 \%$ for $16 \mathrm{~S} ; 0.3-0.8 \%$ for c-mos; and 13-14\% for ND4 (Appendix 2).

\section{Selvasaura evasa sp. nov.}

http://zoobank.org/C3BCC959-A81E-43DF-9D51-356FB9BA9476 Figs $1-4$

Proposed Standard English Name: Elusive Microtegus

Proposed Standard Spanish Name: Microtegúes elusivo

Unnamed Clade 3 (Torres-Carvajal et al. 2016) in part.

Selvasaura sp. (Moravec et al. 2018) in part.

Selvasaura sp. (Torres-Carvajal et al. in press) in part. 


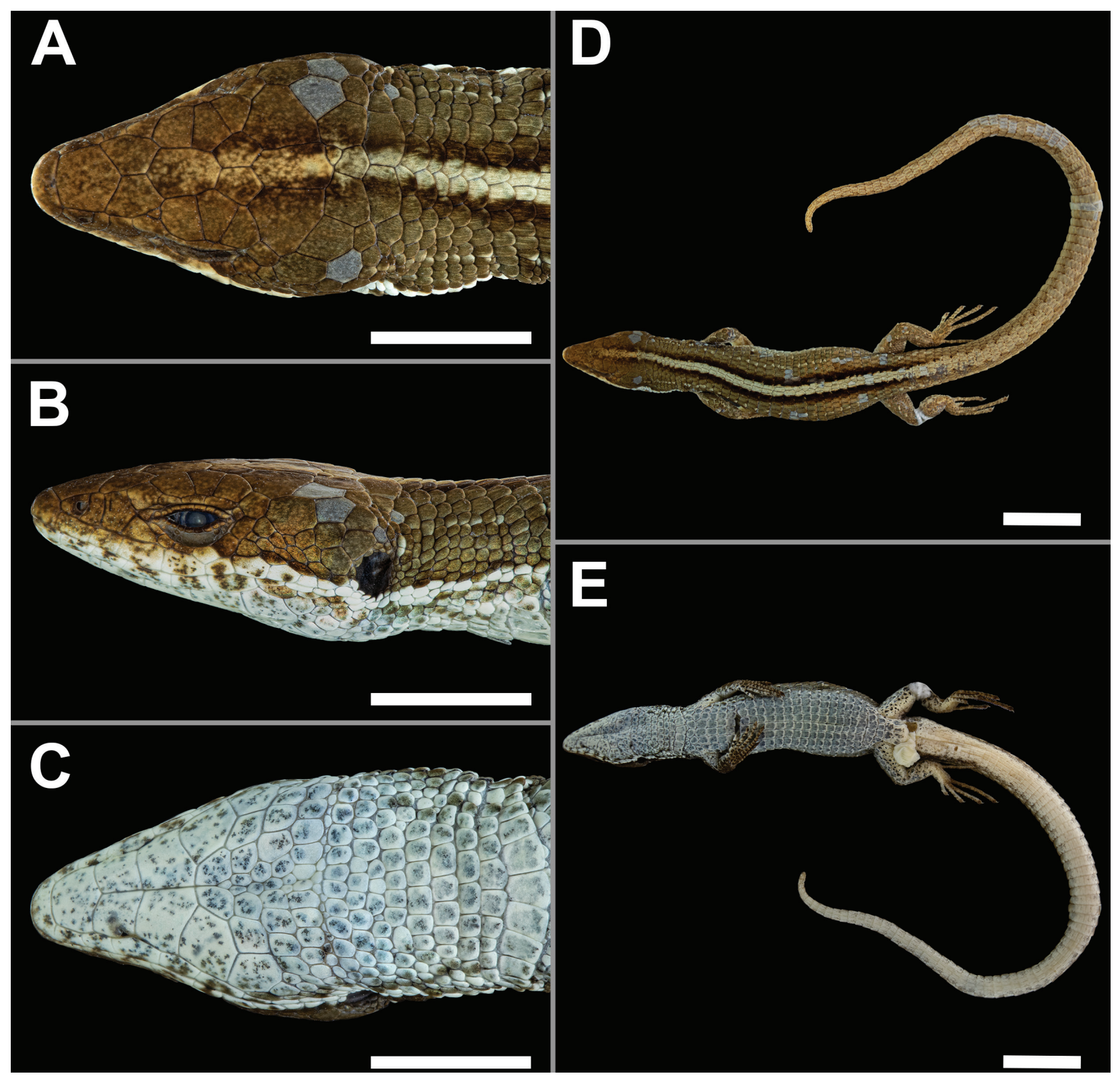

Figure 1. Dorsal (A), lateral (B) and ventral (C) views of the head, and dorsal (D) and ventral (E) views of the body of Selvasaura evasa sp. nov. holotype, CORBIDI 15119. Photographs by Luis A. García-Ayachi. Scale bar: 5 mm (A-C); 10 mm (D, E).

Holotype. PERU • đ̃, adult; San Martín Department, Mariscal Cáceres Province, Huicungo District, Laurel; 06² 41'2"S, 77²4'44.3"W; 2,762 m; 02 Nov. 2014; L.Y. Echevarría, A.C. Barboza and J. Briones leg.; CORBIDI 15119 (Figs 1, 2).

Paratypes. PERU $\bullet 2 q$ adults, 19 subadult, 2 juveniles, collected with the holotype; CORBIDI 15118 (Fig. 3A, B), 15120, 15117, 15115-16 • 2 ○ adults; Amazonas Department, Bongará Province, Yambrasbamba District, Copal; 0546'36.317"S, 7750'47.197"W; 2,582 m; 22 Jun. 2017; P.J. Venegas and J.C. Chávez-Arribasplata leg.; CORBIDI 18900 (Fig. 3C, D), 18901 • 1 juvenile; Amazonas Department, Chachapoyas Province, Chachapoyas District, Gajmal; 06²16'30.885"S, 7741'41.896"W; 2,139 m; 13 Oct. 2018; P.J. Venegas and L.A. García-Ayachi leg.; CORBIDI 19955 (Fig. 3E, F) 1 đ adult; San Martín Department, Rioja Province,
Pardo Miguel District, Fundo Alto Nieva 0540'13.919"S, 7745'45.475"W; 1,938 m; 23 Jan. 2020; L.A. GarcíaAyachi and J. Ormeño leg.; CORBIDI 22197.

Characterization. A small gymnophthalmid (SVL 51.1-52.2 $\mathrm{mm}[\mathrm{n}=2]$ in females and 41.9-46.1 mm [n $=4]$ in males) characterized by: 1) body slender; 2) head pointed, 1.4 to 1.6 times longer than wide; 3 ) ear opening distinct, moderately recessed; 4) nasals separated by undivided frontonasal; 5) prefrontals, frontal, frontoparietals, parietals, postparietals and interparietal present; 6) parietals longer than wide; 7) three supraoculars; 8) superciliar series complete, consisting of four scales; 9) nasal completely or partially divided (behind the nostril); 10) loreal in contact with second supralabial; 11) supralabials usually seven; 12) two pairs of genials; 13) collar present, composed by 9-10 enlarged scales; 14) 33-38 transverse rows of dorsal scales; 15) 20-25 transverse rows of ventral 


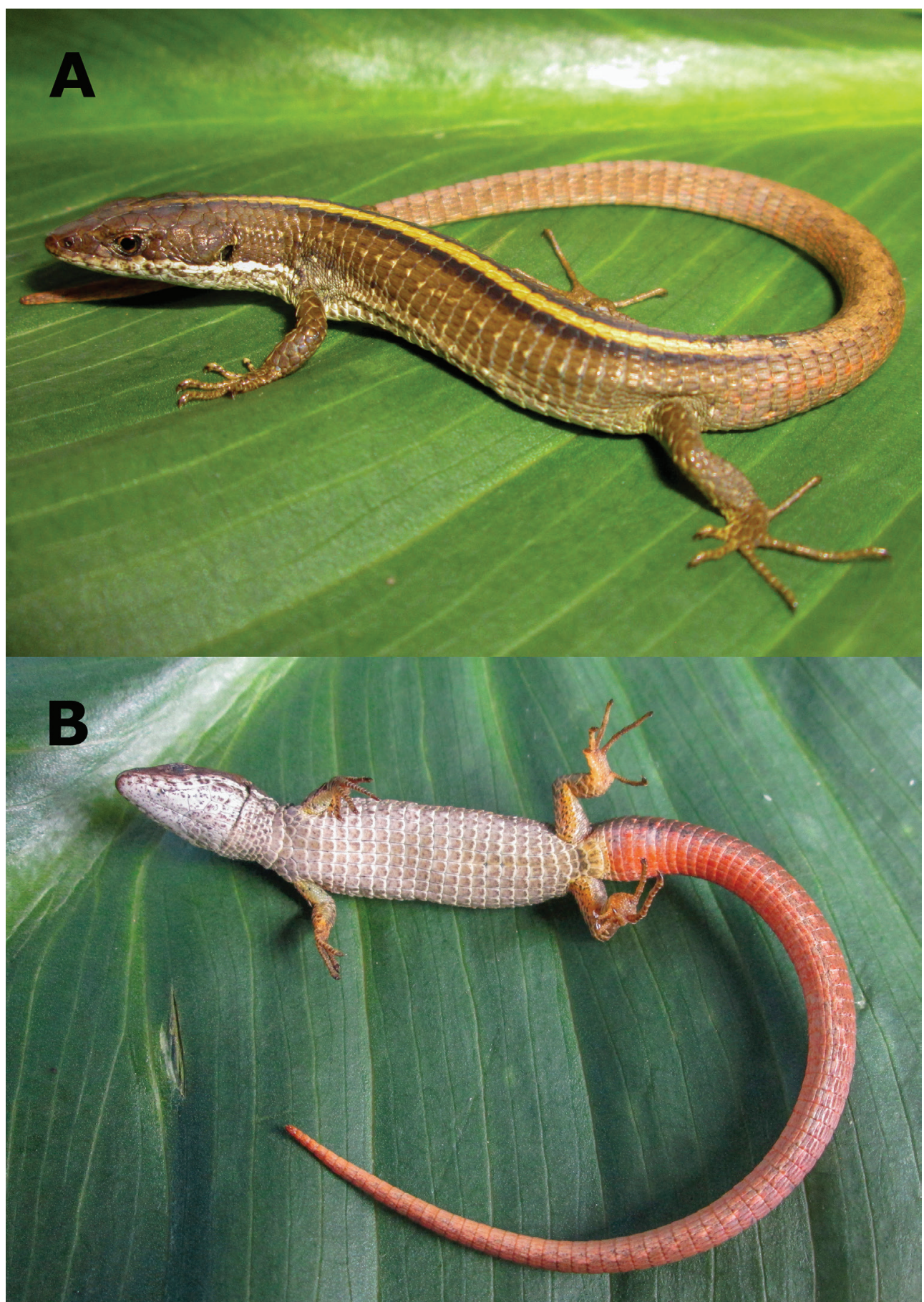

Figure 2. Dorsolateral (A) and ventral (B) views of Selvasaura evasa sp. nov. holotype, CORBIDI 15119, in life. Photographs by L.Y. Echevarría.

scales; 16) 10-12 longitudinal rows of ventral scales; 17) 44-50 scales around midbody; 18) lateral scales at mid-body reduced or absent, present in a maximum of three rows; 19) limbs pentadactyl, all digits clawed; 20) subdigital lamellae under Finger IV 14-19, under Toe IV $17-24 ; 21$ ) femoral pores $7-10$ in females and $9-12$ in males; 22) cloacal plate with four large scales; 23) tail 1.3-1.9 times longer than body; 24) caudals keeled dorsally and smooth ventrally; 25) lower palpebral disc undivided, pigmented or transparent; 26) dorsum brown with a yellow vertebral stripe, bordered by broad dark brown stripes in adult males; 27) cream labial stripe extending up to insertion of forelimb in males, females and juveniles; 28) sides of body brown and cream on ventrolateral region in males, females and juveniles; 29) well defined ocelli usually absent; adults and juveniles with a row of faint ocelli (black outline and cream center) followed by cream spots, usually up to midbody.

Diagnosis. Selvasaura evasa sp. nov. can be distinguished from $S$. brava (character states in parentheses) by having 0-3 lateral rows of reduced scales at midbody (6-7); 9-12 femoral pores in males (7-9); keeled dorsal 


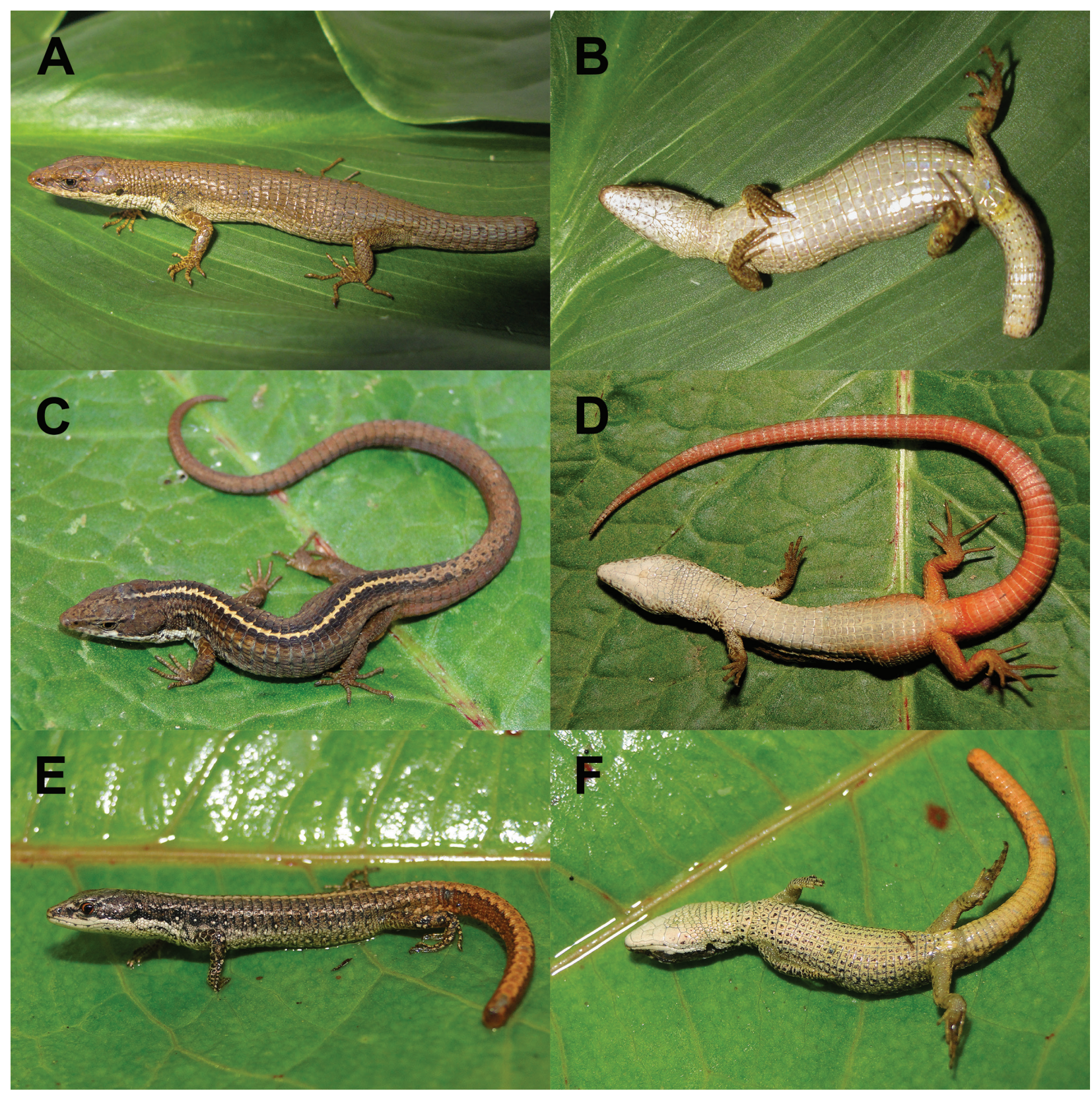

Figure 3. Paratypes of Selvasaura evasa sp. nov.: dorsolateral (A) and ventral (B) views of adult female CORBIDI 15118; dorsolateral (C) and ventral (D) views of adult male CORBIDI 18900; dorsolateral (E) and ventral (F) views of juvenile CORBIDI 19955. Photographs A, B by LYE and C-F by PJV.

scales, usually flanked by longitudinal striae in adults and juveniles (slightly rugose in adults and slightly keeled in juveniles); ventral surface of tail orange in adult males (yellowish white); and a unilobed hemipenis (bilobed). Selvasaura evasa sp. nov. can be distinguished from $S$. sp. Ecuador (character states in parentheses) by having a larger size, SVL 41.9-46.1 mm, $\mathrm{n}=3$, in adult males (maximum SVL $39.7 \mathrm{~mm}$ ); keeled dorsal scales, usually flanked by longitudinal striae (striated); 33-38 transverse rows of dorsal scales (25-32); 10-12 longitudinal rows of ventral scales at midbody (8-10); 9-10 scales on collar (7-9); a yellow vertebral stripe with broad dark brown stripes on each side in adult males (cream or gray with scattered black marks along sides).
Description of holotype. Adult male (CORBIDI 15119); SVL $44.8 \mathrm{~mm}$; TL $86.0 \mathrm{~mm}$; dorsal and lateral head scales juxtaposed, smooth; rostral rectangular, 1.9 times as wide as high; frontonasal pentagonal, as long as wide, laterally in contact with nasals, same size than frontal; prefrontals pentagonal, longer than wide, with medial suture, laterally in contact with nasal, loreal and first superciliary; frontal hexagonal, longer than wide, slightly wider anteriorly, in contact with frontoparietals, prefrontals and supraoculars I and II; frontoparietals pentagonal, longer than wide, with medial suture, each in contact laterally with supraoculars II and III; interparietal hexagonal, lateral borders parallel to each other; parietals polygonal, positioned anterolaterally to interparietal, each in contact 
laterally with supraocular III and dorsalmost postocular; postparietals three, medial one smaller than laterals; $8 / 7$ (right/left) supralabials, fourth below center of eye; six infralabials, fourth below center of eye; temporals enlarged, juxtaposed, smooth; two large, smooth supratemporal scales; nasal divided in two, subtriangular, in contact with rostral anteriorly, first and second supralabials ventrally, frontonasal and prefrontal dorsally and loreal posteriorly; nostril piercing nasal in the center, directed lateroposteriorly; loreal pentagonal; frenocular subtriangular, in contact with loreal, first subocular and third supralabial; three supraoculars, first one the largest; four superciliaries, first one the largest and dorsally extended in contact with prefrontal and loreal; lower eyelid scale single and pigmented; four suboculars, fourth one the largest; three postoculars, similar in size; ear opening round without denticulate margins; tympanum recessed into a shallow auditory meatus; mental wider than long; postmental pentagonal, slightly wider than long, followed posteriorly by two pairs of genials; gulars imbricate, smooth, in ten rows; gular fold complete; posterior row of gulars (collar) composed by enlarged scales, twice as large as anterior gulars.

Scales on nape wider than dorsals; scales on sides of neck small and granular; dorsal scales elongated, imbricate, arranged in transverse rows; scales on dorsal surface of neck striated; 33 dorsal scales between occipital scales and posterior margin of hind limbs; 21 dorsal scales rows in a transverse line at midbody; ventrolateral scales smooth; dorsals separated from ventrals by one (right) or two (left) rows of small scales at the level of the $10^{\text {th }}$ transverse row of ventrals; lateral body fold present; ventrals smooth, longer than wide, arranged in 22 transverse rows between collar fold and preanals; 10 ventral scales in a transverse row at midbody; subcaudals smooth; limbs overlap when adpressed against midbody; axillary region composed of granular scales; scales on dorsal surface of forelimb striated, imbricate; scales on ventral surface of forelimb granular; three thick, smooth thenar scales; supradigitals (right/left): $3 / 3$ on finger I, 7/7 on II, 9/9 on III, $11 / 11$ on IV, $7 / 7$ on $\mathrm{V}$; supradigitals $4 / 4$ on toe I, $6 / 6$ on II, $10 / 10$ on III, $12 / 11$ on IV, 9/9 on V; subdigital lamellae on fingers divided proximally and single distally, $7 / 7$ on finger I, $12 / 13$ on II, $16 / 16$ on III, $16 / 19$ on IV, 12/13 on V; subdigital lamellae on toes divided proximally and single distally, $7 / 7$ on toe I, $12 / 10$ on II, $17 / 16$ on III, $22 / 22$ on IV, $15 / 15$ on V; groin region with small, imbricate scales; scales on dorsal surface of hind limbs striated, imbricate; scales on ventral surface of hind limbs smooth, imbricate; scales on posterior surface of hind limbs granular; 10 femoral pores on each thigh; preanal pores absent; two anterior and four posterior cloacal plate scales.

Measurements and proportions of the holotype in $\mathrm{mm}$ : HL 10.6, HW 7.1, ShL 5.5, AGD 25.4; TL/SVL 1.9; HL/ SVL 0.2; HW/SVL 0.2; ShL/SVL 0.1; AGD/SVL 0.6.

Color of holotype in life. Dorsum brown with a broad yellow vertebral stripe bordered by a broad dark brown stripe on each side, and extending from interparietal to base of tail, where it becomes a light brown stripe.
The vertebral stripe is continuous with a light brown stripe on the dorsal surface of the tail. Dorsal surface of head brown with pale yellow suffusion on frontoparietals and frontal. Lateral surface of head brown. Iris orange. Supralabials and infralabials cream with brown mottling. Cream labial stripe extending posteriorly up to insertion of forelimb. Flanks of body brown, ventrolateral region cream. A longitudinal row of small pale-yellow spots on dorsolateral region. Flanks with two faint ocelli followed by small cream spots, from forelimb insertion to base of tail. Dorsal surface of tail light brown with orange splotches on the sides. Dorsal surface of forelimbs and hind limbs brown; only fingers I and II and toes I and II yellow. Ventral surface of head cream with brown flecks. Ventral surfaces of neck, chest and belly cream with blurred brown splotches on each scale. Ventral surface of tail orange. Ventral surface of forelimbs and hind limbs yellow with brown flecks.

Color of holotype in preservative. Similar to coloration in life. Suffusion on frontoparietals and frontal cream; ventral surface of forelimbs and hind limbs cream with brown spots; ventral surface of tail pale pink on anterior third and cream on the remainder.

Variation. Variations in scale counts and SVL of Selvasaura evasa sp. nov. and comparisons with congeners are presented in Table 1.

Two juvenile (CORBIDI 15116 and 19955) and two adult male (CORBIDI 18900-01) specimens have keeled dorsal scales, without the usual striae flanking the central keel. Male specimens CORBIDI 18900-01 and CORBIDI 22197 lack rows of lateral scales. Specimen CORBIDI 15118 has five superciliaries on left side. Specimen CORBIDI 15118 has six supralabials on left side, and CORBIDI 19955 has eight. The number of infralabial scales is quite variable, 5/5 (CORBIDI 15116), 6/5 (CORBIDI 15118), 6/7 (CORBIDI 15115), 7/7 (CORBIDI 15117, $18900,19955)$, and 7/8 (18901). Femoral pores are absent only in one juvenile specimen (CORBIDI 19955).

All adult males have a similar coloration, only CORBIDI 22197 has a light brown vertebral stripe. Adult females are similar in color to adult males. However, the

Table 1. Variation in scutellation and sexual dimorphism in SVL (mm) of Selvasaura evasa sp. nov. and its congeners, S. brava and $S$. sp. Ecuador.

\begin{tabular}{lccc}
\hline \multicolumn{1}{c}{ Character } & $\begin{array}{c}\text { Selvasaura } \\
\text { evasa } \mathbf{s p .} \\
\text { nov. }(\mathbf{n}=7)\end{array}$ & $\begin{array}{c}\text { Selvasaura } \\
\text { brava } \\
(\mathbf{n}=\mathbf{6})\end{array}$ & $\begin{array}{c}\text { Selvasaura } \\
\text { sp. Ecuador } \\
(\mathbf{n}=\mathbf{3})\end{array}$ \\
\hline Scales in collar & $9-10$ & $9-11$ & $7-9$ \\
Transverse rows of dorsals & $33-38$ & $33-36$ & $25-32$ \\
Laterals at midbody & $0-2$ & $6-7$ & 5 \\
Transverse rows of ventrals & $20-25$ & $22-25$ & $20-23$ \\
Longitudinal rows of ventrals & $10-12$ & 10 & $8-10$ \\
Scales on cloacal plate & $4-5$ & 4 & 4 \\
Lamellae under Finger IV & $14-19$ & $14-16$ & $12-16$ \\
Lamellae under Toe IV & $17-24$ & $18-22$ & $18-20$ \\
Femoral pores in females (one leg) & $7-10$ & 0 & unknown \\
Femoral pores in males (one leg) & $9-12$ & $7-9$ & $9-12$ \\
Maximum SVL in females (mm) & 52.2 & 42.1 & unknown \\
Maximum SVL in males (mm) & 46.1 & 45.9 & 39.7 \\
\hline
\end{tabular}




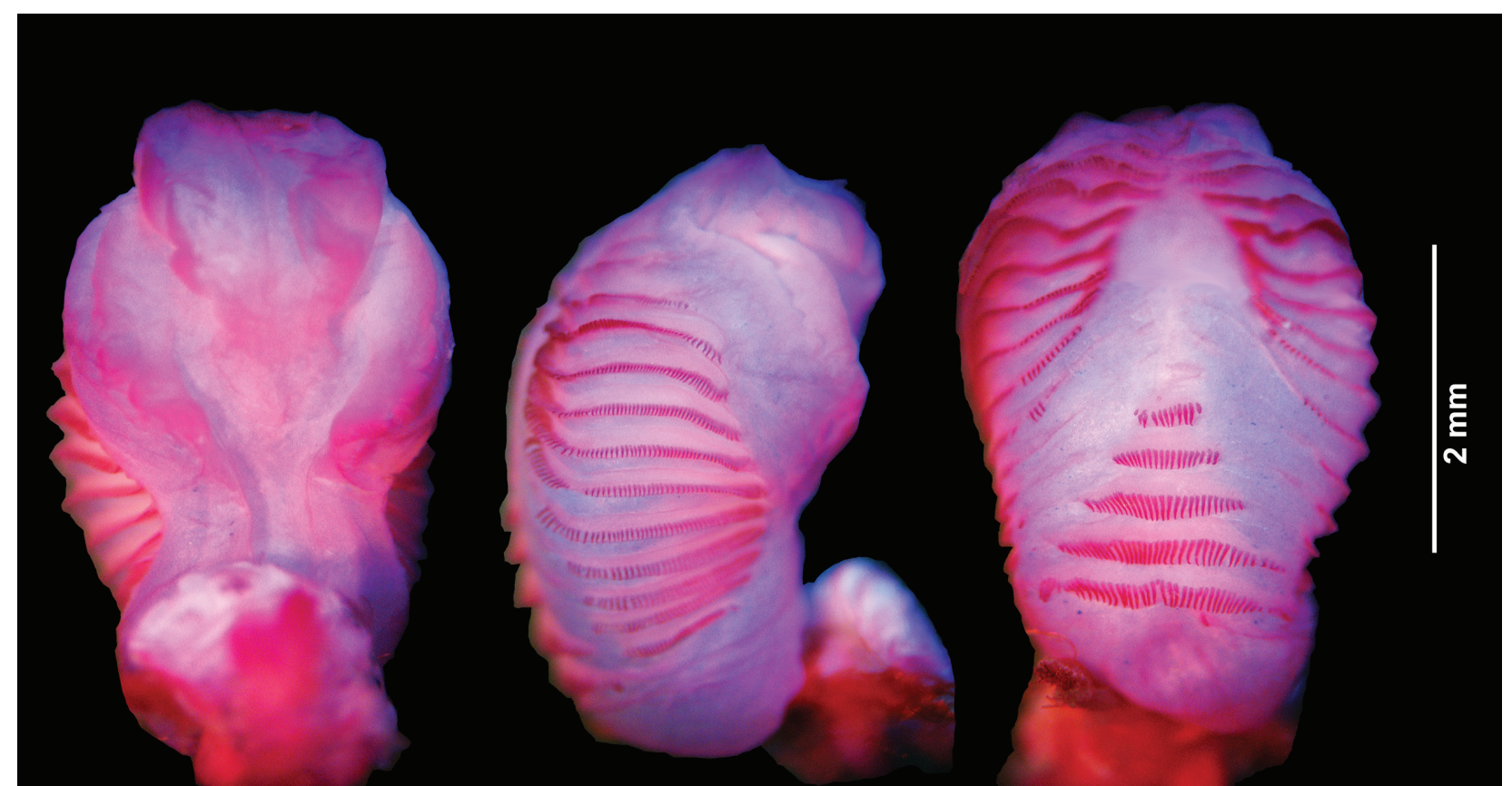

Figure 4. Left hemipenis of Selvasaura evasa sp. nov. (CORBIDI 15119 - holotype) in sulcate (left), lateral (middle), and asulcate (right) views. Photographs by PMSN.

vertebral stripe in females, when present, has a different color pattern. Subadult female specimen CORBIDI 15117 has a light brown vertebral stripe with scattered dark brown spots along margins. Female specimen CORBIDI 15118 (Fig. 3A, B) lacks a vertebral stripe and has two faint black stripes along the dorsolateral margins of the tail. Females lack orange spots on the lateral surface of tail. The ventral surface of tail in females is cream with brown flecks (CORBIDI 15118) or cream with orange margins (CORBIDI 15117).

Juvenile specimens CORBIDI 15115-16 are similar in color to adult males. However, the broad dark brown stripes on each side of the vertebral stripe are discontinuous. Ventrally, the brown flecks on head and the brown splotches on neck, chest and belly are more conspicuous. The tail is orange (CORBIDI 15115) or cream (CORBIDI 15116) ventrally. Specimen CORBIDI 19955 (Fig. 3E, F) has a dark brown dorsum with abundant black flecks and a cream vertebral stripe. It is the only specimen with well-defined ocelli on the anterior portion of flanks, three and seven on right and left sides, respectively, followed by faint ocelli.

One to four faint ocelli (black outline and cream center) are present on the flanks of adult and juvenile specimens. These ocelli are usually followed by cream spots, except in CORBIDI 15118 (Fig. 3A, B) and CORBIDI 18901. Adult female CORBIDI 15117 and adult male CORBIDI 22197 lack ocelli and have a row of three cream spots. The iris is orange, except in one adult female (CORBIDI 15118) and a juvenile (CORBIDI 15115) which have a yellow iris.

Hemipenial morphology. The left hemipenis of the holotype is completely everted and fully expanded, $5 \mathrm{~mm}$ long ( four subcaudals); organ unilobed, capitate, with lobe detached from body and bordered by the branches of the sulcus spermaticus; sulcus spermaticus broad and shallow throughout the hemipenial body, originating at the base of the hemipenis, central in position, and extending in a straight line until it divides into two branches at the half-length of the organ; sulcal branches separated by fleshy fold. Hemipenial body roughly Y-shaped with 15 pairs of transversal flounces, separated by a longitudinal nude area on asulcate face, except for the first five proximal-most flounces; all flounces ornamented with calcified spicules (Fig. 4).

Distribution and natural history. Selvasaura evasa sp. nov. is known from four localities along the eastern slopes of the Andean Cordillera Central, in Amazonas and San Martín departments, northern Peru, at elevations from 1,938 to 2,762 m (Fig. 5). All localities lie in the Peruvian Yungas ecoregion (Olson et al. 2001). Individuals collected at Laurel, in San Martín department, were found in the morning of a cloudy day, inside bromeliads, at ground level and up to $2 \mathrm{~m}$ above the ground, in a patch of poorly drained soil covered by Sphagnus mosses, with scattered shrubs and bromeliads. All specimens were lying inside the water stored in the bromeliads; only CORBIDI 15120 was found dead on the ground, beginning to decompose, missing the right hind limb and a portion of the tail, and with the head partially eaten. Specimens from Copal, in Amazonas department, were found on the border of a small lagoon, under a rock (CORBIDI 18900) and among trash (CORBIDI 18901) in a patch of bunchgrass. Specimen CORBIDI 22197 from Fundo Alto Nieva, was found crossing a road in an area of dense montane forest. Specimen CORBIDI 19955, from Quebrada Gajmal, was collected when it fell from the stick roof of a house surrounded by cattle pasture and patches of secondary montane forest. 


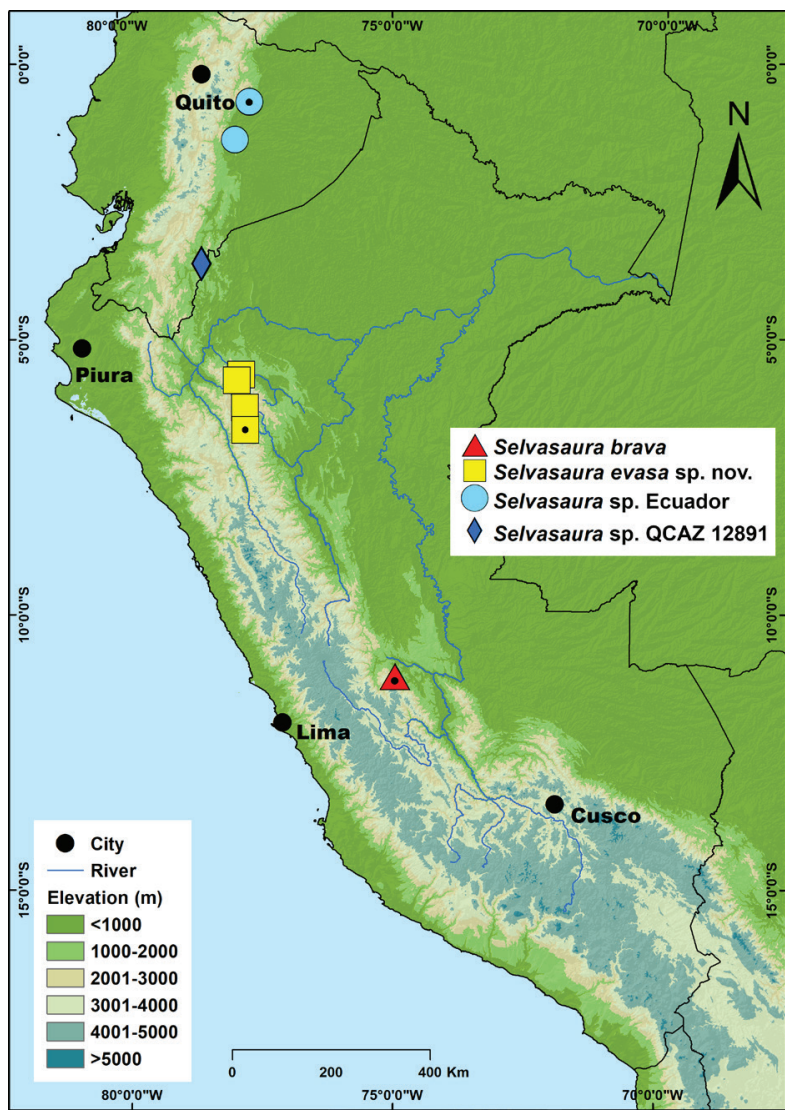

Figure 5. Distribution map of Selvasaura. Symbols with a dot in the middle correspond to type localities.

The two adult females collected at Laurel were gravid, each with two eggs. Specimen CORBIDI 15118 had eggs $12.7-13.7 \mathrm{~mm}$ long, $6.1 \mathrm{~mm}$ wide and $247.3-266.8 \mathrm{~mm}^{3}$ of volume. Specimen CORBIDI 15120 had eggs 12.7$13.4 \mathrm{~mm}$ long, $5.6-5.9 \mathrm{~mm}$ wide and $208.4-244.1 \mathrm{~mm}^{3}$ of volume.

Etymology. The specific epithet evasa is derived from the Latin adjective ēvāsa meaning scaped and refers to the evasive nature of this species. The first specimens of Selvasaura evasa sp. nov. were collected in 2014 despite continuous surveys, since 2003 in 20 localities along the montane forests of Amazonas and San Martín departments, it is only known from four localities.

\section{Discussion}

The results of Moravec et al. (2018) and the Maximum Likelihood tree of Torres-Carvajal et al. (in press) recovered Selvasaura evasa as sister to the clade composed by $S$. brava and an undescribed species from Ecuador (QCAZ 12891). The results of Fang et al. 2020 (see the supplemental files) recovered $S$. evasa as sister to a clade composed by $S$. sp. Ecuador (named as Selvasaura sp. QCAZ 12798) and an undescribed species from Ecuador (QCAZ 12891). The Bayesian Inference tree of TorresCarvajal et al. (in press) recovered S. evasa sp. nov. as sister to an undescribed species from Ecuador (QCAZ 12891), and this clade as sister to Selvasaura sp. Ecuador. Genetic distances for $12 \mathrm{~S}, 16 \mathrm{~S}$, and c-mos among Selvasaura species are similar or higher to the mean genetic distances between Selvasaura and Dendrosauridion or Potamites (Moravec et al. 2018, tables 3, 4), the two Cercosaurinae genera known to be more closely related to the genus (Torres-Carvajal et al. 2016, in press; Moravec et al. 2018; Fang et al. 2020; Vásquez-Restrepo et al. 2020). Therefore, although the results of all previous phylogenetic analyses, the genetic distances and the external and hemipenial morphological characters consistently support $S$. evasa sp. nov. as a distinct and monophyletic lineage in the genus Selvasaura, the relationships between $S$. evasa sp. nov. and its congeners are still uncertain, which prevents us from postulating consistent biogeographic scenarios involving the new species.

The description of a new species of Selvasaura, contributes new states of diagnostic characters of the genus: dorsal scale relief, pigmentation of lower palpebral disc, and presence of femoral pores in females. Furthermore, although the unilobed hemipenes are described and illustrated to Selvasaura sp. Ecuador (Torres-Carvajal et al. in press) and to $S$. evasa sp. nov. (this study), the unilobed condition was not reported to $S$. brava, with the organ being described as bilobed by Moravec et al. (2018). However, it is important to consider that Moravec et al. (2018) described the hemipenial morphology in situ and did not applied specific hemipenial preparation procedures or presented detailed illustrations of the hemipenial morphology to $S$. brava, presenting pictures of an unexpanded and partially everted organ (Moravec et al. 2018 - fig. 7C; MorphoBank pictures: M485676-M485677). Considering the unilobed hemipenis as an uncommon condition in the family Gymnophthalmidae, present only in the subfamily Gymnophthalminae (Nunes 2011; Torres-Carvajal et. al. in press) and as an exclusive characteristic of Selvasaura species within the subfamily Cercosaurinae, the reanalysis of the hemipenis of $S$. brava is desirable. The unilobed condition of the hemipenis as a putative synapomorphy to the genus should be considered until then.

Additionally, the description of Selvasaura evasa sp. nov. contributes with natural history information for this recently discovered and poorly known Andean genus. It is reinforced that the arboreal habitat is still little explored in gymnophthalmids (Chávez et al. 2017; Moravec et al. 2018; Lehr et al. 2019); in fact, S. evasa sp. nov. is one of the few gymnophthalmids known to use the inside of bromeliads as refuge (Oftedal 1974; Fuentes and Rivas 2000; Mijares-Urrutia et al. 2000; Kok 2008; Chávez et al. 2017; Lehr et al. 2019). So far, all known Selvasaura specimens come from localities east of the Andes (Torres-Carvajal et al. 2016, in press; Moravec et al. 2018) along more than $1200 \mathrm{~km}$ in straight line from the northern to the southern-most locality. The diversity of the genus and the distribution and natural history of the described species remain to be further studied. 


\section{Acknowledgements}

The new species of Selvasaura was discovered during fieldwork supported by: Critical Ecosystem Partnership Fund (CEPF) and Fondo de Promoción de las Áreas Naturales Protegidas del Perú (PROFONANPE) with the projects: Updating the status of an endemic harlequin frog from Peru (project number CEPF-108792) and Community forest conservation in the northeastern biodiversity corridor in Peru (project number CEPF-66127); APECO under the research grant "Carlos Ponce del Prado Award (XI edition)"; Global Genome Initiative (GGBN-GGI); and NGO's Ucumari and Yunkawasi. Fieldwork would not have been possible without the logistic support of the following people: Marco Salas from Ucumari, Fanny M. Cornejo from Yunkawasi, Odile Sanchez from PROFONANPE, Mariela Leo and Glen Seitz from APECO. We are especially grateful with our field companions: LYE is indebted to Andy Barboza, Joaquín Briones, and Marco Salas; AGA is indebted to Jesús Ormeño; PJV is indebted to Juan C. Chávez. PJV is grateful to Rainforest Partnership for funding his herpetological research during 2021. PMSN is supported by Conselho Nacional de Desenvolvimento Científico e Tecnológico - CNPq (fellowship number 313622/2018-3). The authors are grateful to William W. Lamar for revising the English language of the manuscript. The authors are grateful to the Centrum für Naturkunde (CeNak) - Center of Natural History - University of Hamburg for supporting the publication of Evolutionary Systematics.

\section{References}

Barry SJ (2012) Preparing scientific specimens. In: McDiarmid RW, Foster MS, Guyer C, Gibbons JW, Chernoff N (Eds) Reptile biodiversity: standard methods for inventory and monitoring. University of California Press, Berkeley, Los Angeles, London, 96-105.

Chávez G, Catenazzi A (2014) A new Andean lizard of the genus Potamites (Sauria, Gymnophthalmidae) from Manu National Park, southeastern Peru. Zootaxa 3774: 045-056. https://doi.org/10.11646/zootaxa.3774.1.3

Chávez G, Catenazzi A, Venegas PJ (2017) A new species of arboreal microteiid lizard of the genus Euspondylus (Gymnophthalmidae: Cercosaurinae) from the Andean slopes of central Peru with comments on Peruvian Euspondylus. Zootaxa 4350: 301-316. https:// doi.org/10.11646/zootaxa.4350.2.6

Crump ML, Scott NJ (1994) Visual encounter surveys. In: Heyer WR, Donnelly MA, McDiarmid RW, Hayek LC, Foster MS (Eds) Measuring and monitoring biological diversity, standard methods for amphibians. Smithsonian Institution Press, Washington DC, 84-92.

de Queiroz K (1998) The general lineage concept of species, species criteria, and the process of speciation. In: Howard DJ, Berlocher $\mathrm{SH}$ (Eds) Endless forms: species and speciation. Oxford University Press, 57-75.

de Queiroz K (2007) Species concept and species delimitations. Systematic Biology 56: 879-886. https://doi. org/10.1080/10635150701701083
Echevarría LY, Barboza AC, Venegas PJ (2015) A new species of montane gymnophthalmid lizard, genus Cercosaura (Squamata: Gymnophthalmidae), from the Amazon slope of northern Peru. Amphibian and Reptile Conservation 9: 34-44. https://www.biodiversitylibrary.org/part/178771

Fang JM, Vásquez-Restrepo JD, Daza JM (2020) Filling the gaps in a highly diverse Neotropical lizard lineage: a new and endemic genus of Cercosaurinae (Squamata: Gymnophthalmidae) with the description of two new species from the Northern Andes of Colombia. Systematics and Biodiversity 18: 417-433. https://doi.org/10.1080/ 14772000.2020 .1783714

Fuentes O, Rivas G (2000) Geographic distribution. Euspondylus goeleti. Herpetological Review 31: 181-182.

Goicoechea N, Padial JM, Chaparro JC, Castroviejo-Fisher S, de La Riva I (2013) A Taxonomic Revision of Proctoporus bolivianus Werner (Squamata: Gymnophthalmidae) With the Description of Three New Species and Resurrection of Proctoporus lacertus Stejneger. American Museum Novitates 3786: 1-32. http://hdl.handle.net/10261/117010

Goicoechea N, Frost DR, de La Riva I, Pellegrino KCM, Sites J, Rodrigues MT, Padial JM (2016) Molecular systematics of teioid lizards (Teioidea/Gymnophthalmoidea: Squamata) based on the analysis of 48 loci under tree-alignment and similarity-alignment. Cladistics 32: 624-671. https://doi.org/10.1111/cla.12150

Harvey MB, Embert D (2008) Review of Bolivian Dipsas (Serpentes: Colubridae), with comments on others South American Species. Herpetological Monographs 22: 57-105. https://doi.org/10.1655/07-023.1

Kizirian D (1996) A review of Ecuadorian Proctoporus (Squamata: Gymnophthalmidae) with descriptions of nine new species. Herpetological Monographs 10: 85-155. https://doi.org/10.2307/1466981

Kok P (2008) A new highland species of Arthrosaura Boulenger, 1885 (Squamata: Gymnophthalmidae) from Maringma tepui on the border of Guyana and Brazil. Zootaxa 1909: 1-15. https:/doi. org/10.11646/zootaxa.1909.1.1

Kumar S, Stecher G, Tamura K (2016) MEGA7: molecular evolutionary genetics analysis version 7.0 for bigger datasets. Molecular Biology and Evolution 33: 1870-1874. https://doi.org/10.1093/molbev/msw054

Lehr E, Moravec J, Lundberg M, Köhler G, Catenazzi A, Šmíd J (2019) A new genus and species of arboreal lizard (Gymnophthalmidae: Cercosaurinae) from the eastern Andes of Peru. Salamandra 55: 1-13.

Lehr E, Moravec J, von May R (2020) A new cryptic genus of terrestrial lizard (Gymnophthalmidae: Cercosaurinae) from the eastern Andes of central Peru. Salamandra 56: 1-15.

Mamani L, Goicoechea N, Chaparro JC (2015) A new species of Andean lizard Proctoporus (Squamata: Gymnophthalmidae) from montane forest of the Historic Sanctuary of Machu Picchu, Peru. Amphibian and Reptile Conservation 9: 1-11. https://www.biodiversitylibrary. org/part/202053

Mamani L, Chaparro JC, Correa C, Alarcón C, Salas CY, Catenazzi A (2020) A new species of Andean gymnophthalmid lizard (Squamata: Gymnophthalmidae) from the Peruvian Andes, and resolution of some taxonomic problems. Diversity 12: e361. https://doi. org/10.3390/d12090361

Manzani PR, Abe AS (1988) Sobre dois novos métodos de preparo do hemipênis de serpentes. Memorias do Instituto Butantan 50: 15-20.

Mijares-Urrutia A, Señaris JC, Arends A (2000) Taxonomía de algunos microtéidos (Squamata) de Venezuela, I: Variación y distribución geográfica de Euspondylus acutirostris y descripción de un nuevo 
Euspondylus del nordeste de Venezuela. Revista de Biología Tropical 48: 671-680. https://doi.org/10.15517/rbt.v48i2-3.18874

Moravec J, Šmíd J, Štund J, Lehr E (2018) Systematics of Neotropical microteiid lizards (Gymnophthalmidae, Cercosaurinae), with the description of a new genus and species from the Andean montane forests. ZooKeys 774: 105-139. https://doi.org/10.3897/zookeys.774.25332

Nunes PMS (2011) Morfologia hemipeniana dos lagartos microteídeos e suas implicações nas relações filogenéticas da família Gymnophthalmidae (Squamata: Teiioidea). PhD Thesis. Universidade de São Paulo, Brazil.

Nunes PMS, Fouquet A, Curcio FF, Kok PJR, Rodrigues MT (2012) Cryptic species in Iphisa elegans Gray, 1851 (Squamata: Gymnophthalmidae) revealed by hemipenial morphology and molecular data. Zoological Journal of Linnean Society 166: 361-376. https://doi. org/10.1111/j.1096-3642.2012.00846.x

Oftedal OT (1974) A revision of the genus Anadia (Sauria, Teiidae). Arquivos de Zoologia 25: 203-265. https://doi.org/10.11606/issn.21767793.v25i4p203-265

Olson DM, Dinerstein E, Wikramanayake ED, Burgess ND, Powell GVN, Underwood EC, D'Amico JA, Itoua I, Strand HE, Morrison JC, Loucks CJ, Allnutt TF, Ricketts TH, Kura Y, Lamoreux JF, Wettengel WW, Hedao P, Kassem KR (2001) Terrestrial Ecoregions of the World: A new Map of Life on Earth. BioScience 51: 933-938. https:// doi.org/10.1641/0006-3568(2001)051[0933:TEOTWA]2.0.CO;2

Pontificia Universidad Católica del Ecuador (2021) Base de datos de la colección de reptiles del Museo de Zoología QCAZ. Versión 2021.0. https://bioweb.bio/portal/ [Accessed 21 June 2021]

Pesantes OS (1994) A method for preparing the hemipenis of preserved snakes. Journal of Herpetology 28: 93-95. https://doi. org/10.2307/1564686

Rojas-Runjaic, FJM, Barrio-Amorós CL, Señaris JC, De la Riva I, Castroviejo-Fisher S (2021) Discovery of an additional piece of the large gymnophthalmid puzzle: a new genus and species of stream spiny lizard (Squamata: Gymnophthalmidae: Cercosaurinae) from the western Guiana Shield in Venezuela. Zootaxa 4950: 296-320. https://doi.org/10.11646/zootaxa.4950.2.4

Sánchez-Pacheco SJ, Nunes PMS, Marques-Souza S, Rodrigues MT, Murphy RW (2017) Formal recognition of the species of Oreosaurus (Reptilia, Squamata, Gymnophthalmidae) from the Sierra Nevada de Santa Marta, Colombia. ZooKeys 691: 149-162. https://doi. org/10.3897/zookeys.691.13595

Sánchez-Pacheco SJ, Torres-Carvajal O, Aguirre-Peñafiel V, Nunes PMS, Verrastro L, Rivas GA, Rodrigues MT, Grant T, Murphy RW (2018) Phylogeny of Riama (Squamata: Gymnophthalmidae), impact of phenotypic evidence on molecular datasets, and the origin of the Sierra Nevada de Santa Marta endemic fauna. Cladistics 34: 260-291. https://doi.org/10.1111/cla.12203
Simpson GG (1951) The species concept. Evolution 5: 285-298. https:// doi.org/10.1111/j.1558-5646.1951.tb02788.x

Torres-Carvajal O, Venegas PJ, Lobos SE, Mafla-Endara P, Nunes PMS (2014) A new species of Pholidobolus (Squamata: Gymnophthalmidae) from the Andes of Southern Ecuador. Amphibian and Reptile Conservation 8: 76-88. https://www.biodiversitylibrary.org/ part/178779

Torres-Carvajal O, Lobos SE, Venegas PJ, Chávez G, Aguirre-Peñafiel V, Zurita D, Echevarría LY (2016) Phylogeny and biogeography of the most diverse clade of South American gymnophthalmid lizards (Squamata, Gymnophthalmidae, Cercosaurinae). Molecular Phylogenetics and Evolution 99: 63-75. https://oi.org/10.1016/j. ympev.2016.03.006

Torres-Carvajal O, Venegas PJ, Nunes PMS (2020) Description and phylogeny of a new species of Andean lizard (Gymnophthalmidae: Cercosaurinae) from the Huancabamba depression. South American Journal of Herpetology 18: 13-23. https://doi.org/10.2994/SAJH-D-18-00069.1

Torres-Carvajal O, Parra V, Nunes PMS, Koch C (in press) A new species of microtegu lizard (Gymnophthalmidae: Cercosaurinae) from Amazonian Ecuador. Journal of Hepetology.

Uzzell T (1973) A revision of lizards of the genus Prionodactylus, with a new genus for $P$. leucostictus and notes on the genus Euspondylus (Sauria, Teiidae). Postilla 159: 1-67. https://doi.org/10.5962/bhl. part.11535

Vásquez-Restrepo JD, Ibáñez R, Sánchez-Pacheco S, Daza JM (2020) Taxonomy, phylogeny and distribution of the Neotropical lizard genus Echinosaura (Squamata, Gymnophthalmidae), with the recognition of two new genera within Cercosaurinae. Zoological Journal of the Linnean Society 189: 287-314. https://doi.org/10.1093/zoolinnean/zlz124

Venegas PJ, Echevarría LY, Lobos SE, Nunes PMS, Torres-Carvajal O (2016) A new species of Andean microteiid lizard (Gymnophthalmidae: Cercosaurinae: Pholidobolus) from Peru, with comments on $P$. vertebralis. Amphibian and Reptile Conservation 10: 21-33. http:// pucedspace.puce.edu.ec/handle/23000/1044

Wiley EO (1978) The evolutionary species concept reconsidered. Systematic Zoology 27: 17-26. https://doi.org/10.2307/2412809

Young KR, León B (2000) Biodiversity conservation in Peru's eastern montane forests. Mountain Research and Development 20: 208-211. https://doi.org/10.1659/0276-4741(2000)020[0208:BCIPSE]2.0.CO;2

Zaher H (1999) Hemipenial morphology of the South American xenodontine snakes, with a proposal for a monophyletic Xenodontinae and a reappraisal of colubroid hemipenes. Bulletin of the American Museum of Natural History 240: 1-168. https://www.biodiversitylibrary.org/bibliography/90073

\section{Appendix 1}

\section{Specimens examined}

Selvasaura sp. Ecuador - $(\mathrm{n}=3)$ Ecuador: QCAZ 5073 \& 12798 Napo, Wildsumaco Wildlife Sanctuary; QCAZ 9140 Pastaza, Zanjarajuno Ecological Center. 


\section{Appendix 2}

Table A1. Uncorrected genetic distances for 12S, 16S, c-mos, and ND4 within Selvasaura.

\begin{tabular}{|c|c|c|c|}
\hline & \multicolumn{3}{|c|}{$12 \mathrm{~S}$} \\
\hline & 1 & 2 & 3 \\
\hline \multicolumn{4}{|l|}{ 1. Selvasaura brava MUSM 32738} \\
\hline 2. Selvasaura evasa CORBIDI 15119 & 5.7 & & \\
\hline 3. Selvasaura sp. Ecuador QCAZ 12798 & 4.8 & 5.7 & \\
\hline \multirow[t]{2}{*}{ 4. Selvasaura sp. QCAZ 12891} & 5.7 & 6.3 & 4.8 \\
\hline & & $16 \mathrm{~S}$ & \\
\hline \multicolumn{4}{|l|}{ 1. Selvasaura brava MUSM 32738} \\
\hline 2. Selvasaura evasa CORBIDI 15119 & 4.7 & & \\
\hline 3. Selvasaura sp. Ecuador QCAZ 12798 & 4.9 & 5.2 & \\
\hline \multirow[t]{2}{*}{ 4. Selvasaura sp. QCAZ 12891} & 5.2 & 5.2 & 4.7 \\
\hline & & c-mos & \\
\hline \multicolumn{4}{|l|}{ 1. Selvasaura brava MUSM 32738} \\
\hline 2. Selvasaura evasa CORBIDI 15119 & 0.3 & & \\
\hline 3. Selvasaura sp. Ecuador QCAZ 12798 & 0.5 & 0.8 & \\
\hline \multirow[t]{2}{*}{ 4. Selvasaura sp. QCAZ 12891} & 0.3 & 0.5 & 0.8 \\
\hline & & ND4 & \\
\hline \multicolumn{4}{|l|}{ 1. Selvasaura brava MUSM 32738} \\
\hline 2. Selvasaura evasa CORBIDI 15119 & - & & \\
\hline 3. Selvasaura sp. Ecuador QCAZ 12798 & - & 13.7 & \\
\hline 4. Selvasaura sp. QCAZ 12891 & - & 13.0 & 14.0 \\
\hline
\end{tabular}

